\title{
THE ROLE OF PEACE IN KELSEN AND LAUTERPACHT'S THEORIES OF INTERNATIONAL LAW
}

\author{
UDK: $172.4: 341$ \\ Accepted: 15. 12. 2018. \\ Review article
}

The purpose of this article is to analyze the role of peace in the theory of international law of Hans Kelsen and Hersh Lauterpacht. The 1960 shift in Kelsen's approach to the role of peace will be elaborated in detail. Along with the theoretical account on the connection between peace and law, both authors have directed their theories to practical matters in the existing international legal system. At the end of the analysis, the similarities and differences between Kelsen and Lauterpacht will be described.

Key words: theory of law, international law, legal values, peace, Kelsen, Lauterpacht

\section{INTRODUCTION}

Hans Kelsen and Hersch Lauterpacht have both developed the connection between peace and international law. The aim of this article is to analyse how they have established this connection, to present some details on how they directed theory regarding this connection to practical considerations in international law and to portray the meaning of the role of peace as seen by both authors.

The second chapter reflects research on the role of peace in Kelsen's theory, established through his concept of law as the coercive order of behaviour. The main change in his approach to the role of peace appears in 1960, when, as a necessary element of the concept of law, he abandoned the function of protecting peace as a part of the regulation of the behaviour.

Nevertheless, the connection, through the concept of coerciveness, remains not only theoretically in place but in describing the content of the existing law as well. The third chapter outlines Lauterpacht's position regarding the role of peace in the context of his methodology of law and his view on the general principles of law. As the postulate of the law, the role of peace is used by Lauterpacht in order to provide legal argument against the existing rules. In my conclusion, the approaches of both authors will be compared. 


\section{KELSEN ON THE ROLE OF INTERNATIONAL PEACE}

Kelsen's considerations on the relation between law and peace are obvious in the two elements of his concept of law: a) law as an order of behavior; b) law as a coercive order.

We have termed the connection in the context of how the law functions in ordering of behavior, the stronger element, and the connection between law and peace in the context of coerciveness, the weaker element. On the one side, the first connection is stronger in that it directly connects the law and peace while the second connection is weaker as it establishes an indirect connection through the lawoperative function in imposing sanctions. On the other side, the difference is based on the scope of requirements. The first connection requires the absence of force in all mutual relations between its subjects (except those in which the official organs are imposing sanctions) and centralization of the law-operative functions (at least adjudication), while the second one requires only a monopoly of force, which can even be decentralized.

\subsection{Kelsen's stronger connection between the role of peace and International Law}

Kelsen has postulated "the order of behavior" as the necessary characteristic of every legal system. Legal theory and doctrine, commonly describe international law as the body of rules which, primarily, govern the behavior of the states (Kelsen, 1952, p. 3). From the characteristic that the law governs behavior through the application of general norms in particular situations, it is possible to presuppose that subjects in the society governed by law will necessarily accept the value of peace at least in some periods of the regulation of their community life. ${ }^{1}$ Instead of this conclusion, however, it seems as though Kelsen has taken an all or nothing position. First, he considers that the protection of peace is the absence of coercive interference, in all spheres of interest of its subjects (except in the case of sanctions), is the necessary element of the concept of law (Kelsen, 1948, p.14) and later, he claims that such a function is not necessary for law at all (Kelsen, 1960). More precisely, Stanley L. Paulson (2017a, p. 598) tales note of three phases in Kelsen's writing. In his very early work, Kelsen accepts that law is the means for such a function, but voices his opposition to the idea that it is a component of the concept of law (Hauptprobleme der Staatsrechtslehre, 1911). Later, in the period from 1942 to 1960 , Kelsen considers such a function inside the concept of law, and finally, in 1960 he retracts that idea.

1 Only if we imagine the normative system which prescribes the use of violence in all relations between its subjects as the desirable behaviour, then peace seems not to appear as the value of that system. Even in that situation, in case of a dispute on breaching the general norm which prescribes violence, for making a decision on delict and sanction a peaceful period in the community will be required. 
Although Kelsen after 1960 no longer considers that function as a part of the concept of law, in that latter phase of his work, Kelsen notices a tendency common to all legal systems concerning the "legal value to be realised", namely, the value of peace as the prohibition of the forcible interference in all 'private' spheres of the subject's life. In his words, "it is the tendency gradually and increasingly to prohibit the use of physical force from man to man" (Kelsen, 2005, p. 36).

In that latter phase, the consideration on the function of law to guarantee the peace in all relations is reduced to the claim that pacification of the legal community by the legal order is an "objectively determinable fact" (Kelsen, 2005, p. 48). Nevertheless, it is possible to question whether that fact can be explained without considering at least the contingent, but the lasting characteristics of the subjects of law. If the law is an order of behavior, it can be assumed that the law always has some functions that depend on the characteristics of its subjects, although it does not mean that all legal orders have the same functions at all times. In the previous phase, Kelsen indirectly refers to the characteristics of the subject of law when describing the tendency of imposing restrictions on forcible interference in the sphere of individual life. "A community, in long run, is possible only if each individual respects certain interests - life, health, freedom and property of everyone else, that is to say, if each refrains from forcibly interfering in these spheres of interest of the others" (Kelsen, 1949, p. 22). The consideration of the characteristics of the subjects of law seems to be crucial for the tendency towards pacification. Hart showed how exactly this consideration can be used to explain the differences in pacification in national and international communities. Before doing that, he has described in detail the minimum substantive content of the legal system based on the lasting characteristics of the subjects of law (Hart, 2015, pp. 193-200).

Even if we look only at Kelsen's explicit account on the tendency towards pacification, without connecting it with the permanent or lasting characteristics of its subjects, it confirms that there is a stronger connection between peace and international law for as long as this tendency exists.

\subsection{Kelsen's weaker connection between the role of peace and international Law}

Besides the connection established through the functions of law regarding the regulation of behavior, Kelsen establishes the connection between law and the role of peace in elaborating coercion as a characteristic of his concept of law.

The system of norms is coercive when it contains norms reflecting the community's monopoly on the use of force in reacting to normatively defined undesirable behavior, which is called a delict. "If a social order provides that coercive acts shall be performed only under definite conditions, determined by it, and only by definite individuals, likewise determined by it, and if we consider these individuals as organs of the community constituted by the social order, we may say 
that the social order reserves the employment of force to the community. Such a social order establishes a force monopoly of the community" (Kelsen, 1952, p. 14). The law is by definition an order with the monopoly of force.

The reaction of the community organs towards a delict is called a sanction. The function of law to impose sanctions for delicts also means that the function of law is to redress the violation of rights (Kelsen, 2001, p. 4 and 6). Kelsen defines the reaction of the community to a delict as legal security and legal security is defined as relative peace (Kelsen, 2001, p. 6). In that way, the monopoly of force restricts the situations in which the use of force arises.

The necessary element of law is not only that it empowers legal organs to use force by means of sanctions but also that it reserves, in principle, the use of force to these organs alone. "Law is an order according to which the use of force is generally forbidden but exceptionally, under certain circumstances and for certain individuals, permitted as sanction" (Kelsen, 1948, p. 22; see also Kelsen, 1952, p. 15 and 18). The empowerment norm to impose sanctions can be described as determining the following conditions for the use of force: a) a legal organ is authorized by the order to use force, whereby in the case of self-help the authorization is provided only to the injured party acting as the official organ; b) authorization refers only to the situation of a delict; c) the use of force in other situations is, in principle, prohibited as a delict. This last condition means that the situation of a delict, in principle, includes the use of physical force which is not a sanction. When Kelsen mentions the use of force which is in principle forbidden ('relative peace'), he refers to the exception in the use of force by official organs implementing sanctions. Nevertheless, there is no reason to exclude the possibility that the legal organ itself may determine situations when private persons can use force without committing a delict. The legal system can institutionalize exceptions, for example, when a duel is permitted by the legal order or the use of force is permitted towards some groups within the society without sanction. Apart from these situations, the use of force can be said to be forbidden. This broader understanding makes it possible to conceal Kelsen's concept on the monopoly of force with his 1960 shift regarding the function of law to guarantee the peace in all relations between its' subjects.

Kelsen's concept of law is not limited only to systems with centralized legal organs paradigmatically described as state-like legal systems. He finds the monopoly of force - centralized or decentralized - to be necessarily characteristic of law that distinguishes the legal order from other social orders. The legal limitations on the use of force are needed if any system of norms is to be considered as law. These limitations are established by the norms respecting legal coercion, which limits the use of force to situations of the implementation of law and to the situations that do not count as delicts. It is only if these norms do not exist that the use of force is absolutely uncontrolled. In such a social order, there is no monopoly of the community on the use of force and consequently no law at all, according to Kelsen's concept. 
A normative system with decentralized legal organs for the use of force is also considered a legal system for it, too, limits the use of force. Therefore, the monopoly of force as a distinguishing characteristic of the legal order is also applicable to international law. Although war is not necessarily prohibited by international law, it is always controlled by law. In primitive systems of international law in which war is not prohibited, the use of force is nevertheless limited. Even in decentralized legal systems such as the primitive system of international law, where the institutional practice of self-help is, by rule, allowed, the force that purports to be legal must be used only in the way the legal organ would use it, and this means in accordance with the law and as an implementation of the decision reached by the application of legal norms. We can add that other non-official uses of force could be allowed only if that are not considered as delicts. This broader concept of law with a decentralized monopoly of force makes it possible for Kelsen to include the international normative system, in which there is no centralized organ empowered to impose sanctions, under the concept of law.

\subsection{The value of peace after 1960}

In the second edition of the Pure Theory of Law (1960), Kelsen indicates that he has modified his view on the relation between law and peace. But was that an undeniable change from the point of view on the legal order as the coercive order?

\subsubsection{Difference between the primitive and developed legal order}

Firstly, the order with a decentralized monopoly of force in which self-help prevails, is, after 1960, still considered by Kelsen to be a legal order in which minimal protection against the use of physical force exists. Secondly, even before 1960, Kelsen ascertains a difference in the degree of peace protection between the primitive and the developed legal order.

The change appears because, from then on, Kelsen assumes that the "real" function of the protection of peace exists only in the latter case. He "assumes that pacification of the legal community takes place only on that [higher] level of legal development" and "he can hardly assume even a relative pacification of the legal community so long as the law is still in primitive condition" (Kelsen, 2005, p. 38). The primitive conditions that Kelsen mentions are numerous: absence of compulsory adjudication, nonexistence of the centralized executive organ for the use of force, blood revenge and the duel as legal institutions, permission to kill slaves and aliens, situations in which war is not prohibited in relations between states. It seems that even the Charter law has no "real" peace securing function due to its lack of compulsory adjudication. Based on the observations of the historically primitive orders, which Kelsen still considers legal orders, and due to his new categorization of the pacifying function, he concludes that securing peace is not an 
essential moral value common to all legal orders or an essential function of the law (Kelsen, 2005, p. 38).

But if we return to the beginning of his 1960's explanation of the relations between the legal order and peace, we will find claims that "the aim of collective security is peace" and that minimum collective security exists in the decentralized legal order. He continues with the statement that "by establishing a monopoly of force in the legal community, the legal order pacifies this community" (Kelsen, 2005, p. 37). Accordingly, a primitive legal order is also an order of peace by virtue of the normative determinations on the conditions for the use of force. According to Kletzer, it is a situation of "messy peace"; it is sociologically a situation of war but legally interpreted a situation of peace-keeping; it is not a moral demand of the (primitive) order that there be peace, but legal declaration of a certain force to be the force of law; it might be seen as a peace situation only in name, but it is the beginning of the peace-keeping process that can be 'tidied up' by the process of centralization; and peace-keeping presupposes peace (Kletzer, 2018, p.39).

It seems that we could reconcile the two positions if we differentiate between peace in the primitive legal order and peace in the developed legal order. Both kinds of order protect peace by means of a legal determination of the conditions for the use of force. In the primitive order, the conditions are primarily formal regarding the implementation of sanctions, and less efficient for securing peace for all members of the society. In the developed order, the conditions are formal regarding sanctions but they are also more substantive in that they cover the overall protection from forcible interference in all the spheres of the subjects' interests e.g. life and property. They are also more efficient with respect to the determination of delicts in a concrete situation,

\subsubsection{Difference between two characteristics of the basic norm}

The second edition of the Pure Theory of Law (1960) brings forth another dilemma in the relation between law and peace. Kelsen claims that no value transcending positive law is inherent in the basic norm of international law and that the legal order is not valid by virtue of assuming the value of peace (Kelsen, 2005, p. 216). Accordingly, peace is not the necessary element of the concept of law. (Kelsen, 2005, p. 216). At the same time, as mentioned above, he claims that the normative system is a legal system only if a monopoly of force is established and therefore the peace-keeping introduced. The contradiction can be analysed based on Stanley L. Paulson's description of the basic norm characteristics (Paulson, 2018), namely the empowerment characteristics.

Two empowerment characteristics of the basic norm can be distinguished: a) the empowerment of the creation of norms and b) the empowerment of imposing the sanctions. Any legal system necessarily performs law-operative functions which correspond to these two basic norm characteristics. To state, as a hypothesis, that the legal order contains the basic norm which empowers legal organs to impose 
sanctions, is the same as to state that the legal order has the function of reacting to a delict which, in principle, contains behaviour of using force other than a sanction. In that way the peace-keeping function is established.

Regarding municipal law, Kelsen describes the empowerment characteristic of the basic norm in the following way. "If the law is conceived as a coercive order, then the formula by which the basic norm of a national order is expressed runs as follows: 'Coercion of man against man ought to be exercised in the manner and under conditions determined by the historically first constitution." (Kelsen, 2005, p. 50). A similar formula can be found for international law: "Coercion of state against state ought to be exercised under the condition and in the manner, that conform with the custom constituted by the actual behavior of the states." (Kelsen, 2005, p. 216). This formula demonstrates that Kelsen contemplates that the basic norm, besides the reference to the first source of law (constitution, custom), also contains reference regarding coercion. We are not sure that this formula alone could satisfy his definition of law without the determinations on empowerment mentioned above, since we can imagine the constitution prescribing that "coercion should be exercised as the part of religious ceremony by all subjects every morning but not on Sunday', as the only condition for the use of coercion. Nevertheless, even this formula, by requiring conditions on the use of force, presents the limitation of the use of force and consequently the protection of peace, that is, of the absence of force at least in some situations.

When the first characteristic of the basic norm is applied to the normative system alone, the protection of the value of peace becomes the legal norm, only if it is created by a custom or a first constitution. While, according to the second one, the protection of the role of value is directed to the norm of the legal system based on the hypothesis of the law-enforcing organ's authority, granted by a legal order, to sanction a delict. If the particular normative order does not empower any legal organ to impose sanctions, there is no legal system. Kelsen claims that international law is a legal system because states are empowered to produce norms through custom and states as decentralized legal organs are empowered to use force only in the case of illegal acts.

Both empowerments are the hypotheses of general international law as perceived by Kelsen. While the first one - custom as the source of international law - is explicitly stated in the formula as the empowerment based on the basic norm, it can be interpreted that Kelsen see the second empowerment as the one 'delegated' by the basic norm through a custom that, on the other hand, he presupposes, has produced such an empowerment of states so as to impose sanctions. Even in that case, the two hypotheses are necessary since "[t]ogether with the basic norm the definition of law as a coercive order is presupposed" (Kelsen, 2005, p. 50). Without the empowerment of the sanctioning organ, the international order is only a customarily moral order. "If the law is not defined as a coercive order, but only as an order established according to a basic norm [... a] legal norm established by custom could not be distinguished from a customarily established moral norm at 
all" (Kelsen, 2005, p 53). Notwithstanding the interpretation that, at least in logical relations, the empowerment on custom precedes the empowerment on sanctioning organs, due to the definition of the law as the coercive order, the protection of peace has to necessarily appear in the international legal order.

Additionally, we can continue with the analysis of the claim of 'deriving' the second hypothesis from the first one in more detail. The first hypothesis authorizes states to create norms by custom, and the second one empowers states themselves to impose sanctions. As mentioned before, the acceptance of the first hypothesis without the second one is insufficient to view the international normative system as international law. Since the basic norm empowers the production of law through custom, the 'international legal order' would begin with the production of norms by the appearance of custom, but at the same time it would not be established by definition until custom has established a sanctioning organ. It does not make sense to say that the 'international legal order' could by custom decide not to have any sanctioning organs. Not, at any rate, if the sanctioning organ is necessarily characteristic of law. Therefore, the moment of the norm-creating empowerment cannot be separated from the moment of the sanction-imposing empowerment. If these two hypotheses in international law have to come together, then they are both incorporated in the basic norm. Consequently, it can be assumed that the basic norm 'prescribes' directly the empowerment of the sanctioning organ and that it is not derived from the first hypothesis.

\subsubsection{Difference between the minimum and maximum content of the value of peace}

Finally, Kelsen rejects the thesis that law in its essence represents a moral minimum - that a coercive order, to be regarded as law, must fulfil a minimum moral postulate. The legal value does not represent a moral minimum in the sense that the peace value is an element essential for the concept of law (Kelsen, 2005, p. 64).

Nevertheless, Kelsen considers that law constitutes value, legal value, based on the fact that it is a norm which implies that man ought to behave in a certain way (Kelsen, 2005, p. 65). "The relative moral value is established by a social norm that man ought to behave in a certain way. Norm and value are correlative concepts [...] The statement that "law is moral by nature" does not mean that law has a certain content, but that it is a norm - namely a social norm that man ought to behave in a certain way [...L]aw constitutes a value precisely by the fact it is a norm: it constitutes the legal value which, at the same time, is a (relative) moral value; which means that the law is norm" (Kelsen, 2005, p. 64).

The value of peace understood as the absolute prohibition of interference in different spheres of interests might be substantial enough to count among other moral values which are not a part of the content of the law. But the legal value of normativity is formal enough to avoid any implication of a minimal moral postulate. Likewise, peace as the monopoly on the use of force can then also be seen as a legal 
value. This meaning of peace refers only to the authority of the legal order to react through legal organs to the use of force, other than as a sanction. This meaning of peace refers to 'messy peace' of controlling the use of force as mentioned before.

\subsubsection{Realistic theory of law after 1962}

After 1962 Kelsen substituted the thesis that 'law is normative' (based on the Kantian-inspired basic norm) with the thesis 'as if the law were normative' (Paulson, 2017b, p. 883-885). This shift could be interpreted as a move towards the realistic theory of law which could also be seen as requiring the modification of his considerations on general international law. The understanding of the basic norm as a fiction addresses not only the question of normativity but also the question of the basic characteristics of the law contained in the basic norm such is the monopoly of the order to impose sanctions. Nevertheless, whatever the final result of the theoretical discussion on the Kelsen's basic norm after 1962 might be, the coercive character of the legal order remains in Kelsen's definition of the law. It was the ground for his account on the content of general international law, namely that war and reprisals were the content of general international law if it were law at all. And this position was not changed by Kelsen after 1962 .

\subsection{Practical implications of Kelsen's theory of law}

Kelsen has not confined himself to the theory of law but has addressed practical issues respecting international legal norms as well. He claims that his conceptual characteristic of war and reprisals, as the sanctions of international law, find their confirmation in general international law, which is customary law. "It may be argued that, in accordance with general international law, a forcible interference in the sphere of interest of a state, that is reprisals or war, is permitted only as a reaction against a violation of law, that is to say as sanction. Since the enforcement actions determined by Articles 39, 41 and 42 of the Charter constitute forcible interference in the sphere of a state, they must be interpreted as sanctions if the Charter is supposed to be in conformity with general international law" (Kelsen, 1951, p. 735).

It is very difficult to prove that norms on war and reprisals as the sanctions of the legal organs were really part of general international law, and not simply Kelsen's inclination in his concept of the existing normative system. Francois Rigaux considers this attempt as blurring the distinction between international law and international morality. "Coming back to the juridical nature of international law as a coercive order based on the belum iustum doctrine, one cannot dismiss the thought that the doctrine is more an article of faith than an observed reality. When Kelsen contemplates the positive aspects of the just war, he inevitably blurs the distinction between international law and international morality: the conviction that war is a delict is not supported by general international law [...] In any event, 
the belium iustum doctrine, which is the cornerstone of Kelsen's characterization of international law as a legal order, is not devoid of references to international morality in his system and does not fit properly his nomological approach" (Rigaux, 1998, p. 325). Oliver J. Lissitzyn considered some practical problems regarding Kelsen's concept of sanction, as the result of his "misplaced effort to squeeze international law into his conception of 'law' as a 'coercive order' backed by physical force" (Lissitzyn, 1954, p.306).

The account of a decentralized monopoly of force is based on these hypotheses and not on the factual norms of international law. Even when Kelsen describes historical facts to prove that the norm imposed on states in the form of sanctioning organs is accepted by states as a part of the general international law, which is not a convincing description of international relations, that does not have any influence on the presupposed empowerment hypotheses and his scientific consideration of the international normative system as law. His effort to prove the factual existence of the sanctioning theory in general international law is important as a means of strengthening his argument when interpreting the international norms in light of his theory, that is, in accordance with general international law.

The unclear position regarding the continuation of the existence of general international law after the Charter came into force, can be understood as Kelsen's hesitancy over the strategy of established critics of the Charter: de lege lata critics based on his concept of law projected into the existing general international law or critics based on detecting the deficiencies in the posited law and eventually proposing some de lege ferenda improvements. In the "Law of the United Nations" (1951) the first approach is obvious when he interprets some of the Charter's articles in conformity with his view on the content of general international law.

The interpretation of norms in light of his concept has to be of great importance when comparing general international law, which according to Kelsen, confirms his thesis on war and reprisals as sanctions in international law, with the Charter law, which, he claims, purports to become general international law:

Nonfulfillment of a treaty obligation, e.g., may not be considered by the Security Council or by the General Assembly as a threat to or breach of the peace, and hence not as a delict under the Charter, but it is a delict under general international law. However, it is a delict under general international law only because general international law authorizes the contracting party whose interest is violated by the nonfulfillment of the treaty to resort to reprisals or war against the other contracting party responsible for the nonfulfillment (Kelsen, 1952, p. 57).

The consequence of the gap between the Charter and general international law on sanctions, which is of course the same as his conception of law, is significant:

[T] he Charter does not provide for collective sanctions to be taken by the Organization against every conduct of a state which, under general 
international law, is an international delict. This is no improvement of general international law; and if a legal obligation to behave in a certain way is assumed to exist only if a sanction is provided as a reaction against the contrary behaviour, the Charter has the undesirable effect of depriving of their legal character all obligations established by general international law which are not at the same time obligations under the Charter" (Kelsen, 1952, p. 58).

This is the first difference between general international law and the Charter law. It can be summarized in the following way: general international law provides sanctions for a greater range of conduct, while the Charter provides sanctions only for a very modest range of conduct limited by the legal standard of "threat or use of force". If the sanction is considered as a kind of control of violence as described above, then a broader scope of relations is submitted to peace-keeping function under the general international law. The second difference is that, according to general international law, there is a legal possibility that every dispute may be resolved, although through the use of wrong means, while under the Charter there exists a possibility that some disputes may never be resolved (Kelsen, 1951, p. 270). Thirdly, while under general international law the legal use of force was aimed at maintaining the existing law, the Charter enables the use of force by the Security Council not necessarily only for the purpose of maintenance or restoration of the existing law (Kelsen, 1951, p. 294). In other words, the positive legal order established by the Charter is more a rule of peace between the states and less a rule by law, while general international law is less a rule of peace and more a rule by law. Kelsen tries to resolve this problem of "law without peace" and "peace without law" by the concept of "peace through law". It is the peace achieved through compulsory adjudication for all international disputes (Kelsen, 2008).

\section{LAUTERPACHT'S VALUE OF INTERNATIONAL PEACE}

In the previous section we have focused on Hans Kelsen's elaboration of the connection between peace and law. In this second section we will explain why we consider that Hersch Lauterpacht assumes the value of peace to be a necessary element of the law based on his methodological approach to law. Before we focus on the elaboration of the values of peace, which is an important part of Lauterpacht's understanding of law, we will explain his view of the conception of the law in more detail.

\subsection{Lauterpacht's methodological approach}

Lauterpacht does not make a conceptual distinction between municipal and international law. Following the general conception of law, he provides the definition of international law as the body of the rules of conduct, enforceable by external sanction, which confer rights and impose obligations primarily upon states 
(Lauterpacht, 1978, p. 9). He does not, like Kelsen, broaden the concept of law with hypotheses that are according to Lauterpacht 'artificial'. He does not make any conceptual distinction between municipal and international law, and in light of the former characteristics, the shortcomings of international law become obvious. They "impair the legal nature of what is described as international law but they do not destroy it altogether" (Lauterpacht, 1978, p.31).

The first reason, mentioned in his broader set of law characteristics, that individual defects of international law do not destroy international law, is a hypothesis, set up at the request of judges and legal scientists, that 'we' do not regard them as permanently associated with it and as inherent in its very nature, in the sense that it is a system of law intrinsically different from that of the State" (Lauterpacht, 1978, p. 31). This can be understood as a de lege ferenda request to address some of the deficiencies of international law. But some of the characteristics, which are by Lauterpacht 'translated' in his general principles of the existing law, judges "ought" to respect and they ought to change other norms of the positive law which oppose such principles. The second reason is that it seems, according to Lauterpacht, that the malfunctioning results of one defective characteristic can be replaced by the results of other characteristics.

Nevertheless, later in the "Functions of Law", we find that he considers some characteristics as necessary. As we will see later, the value of peace, understood as the postulate of 'juridical logic', is the necessary characteristic of law. The normcreating, norm-applying and norm-enforcing characteristics of law, according to his writing in the "Functions of Law", are the necessary characteristics, but the form of their appearance, at least for some of them, is only essential. For example, sovereign law-making authority is important for law and for some other characteristics of law, but custom can also serve the purpose of law creation. The centralized enforcement organs are, in the same vain, essential, but their purpose can be fulfilled by the institution of self-help (Lauterpacht, 2000, p. 441). The legal order without the compulsory adjudication of ascertain disputed rights, appears to be more problematic. In the best case, it would be a 'rudimentary legal order'. At the same time Lauterpacht considers that the objectivity of the normative order disappears in the case of deficient production of norms through custom and the absence of compulsory adjudication. The objectivity of law seems to be a necessary characteristic of the law and in that case compulsory adjudication is a sufficient characteristic. It might not be necessary under the condition that the other two institutional characteristics are such that they can neutralize the defects of the system without compulsory adjudication. Lauterpacht has emphasised that certain other defects can hardly be resolved without compulsory adjudication and if that is true, compulsory adjudication could be a serious candidate for becoming the necessary characteristic in his conception of law.

By referring to these three institutional characteristics, Lauterpacht maintains that "it is permissible to ignore the vitiating consequences of any single defect only if other essential elements are present to neutralize the results of the shortcomings in 
one particular sphere. To assert the possibility of the existence of a legal system in which all these elements are lacking is to reduce the conception of law to a shadow of its own self, or else to apply it in a meaning different from that usually attached to it" (Lauterpacht, 2000, p. 441).

The postulates of law, which Lauterpacht proposes in his conception of law, are not only theoretical prescriptions. Through the general principles of law, they are integrated as a part of the positive legal system. They are derived from the "reason of the thing" which comes from the existence and needs of the international society conceived as a community of States under the rule of law. "They are the result of the application of general principles of law - including the acknowledged general principles of international law itself - to the relations of States and, in proper cases, of the individuals who compose them" (Lauterpacht, 1978, p. 54). Although they do not override custom and treaties, but rather supplement them, the norms produced by this source can be interpreted in reference to the general principles of law and those principles are to be used for resolving the problems of the immaturity of positive international law induced by states (Lauterpacht, 1978, p. 54).

\subsection{Lauterpacht's value of peace as peace through law}

Hersch Lauterpacht clearly states that the value of international peace has the same meaning as the peace which exists in the municipal legal systems. According to Lauterpacht, the function of law is to preserve peace and "[i]ts fundamental precept is, 'there shall be no violence'." (Lauterpacht, 2000, p. 72). This is the reason why a judge cannot refuse to adjudicate. For him, ,,peace is pre-eminently a legal postulate. Juridically it is a metaphor for the postulate of the unity of the legal system. Juridical logic inevitably leads to condemnation, as a matter of law, of anarchy and private force" (Lauterpacht, 2000, p. 438).

As the fundamental postulate of law, the value of peace is included in the general principles to be applied by judges. For example, when considering the existing rule against the compulsory adjudication, the value of peace presents one of the main reasons why this rule should be abandoned. The argumentation is based on the claim that this rule conflicts with "the general principles of law and the conception of law itself as generally recognized." (Lauterpacht, 2000, 431). As we have seen the protection of the value of peace belongs to such principles and the conception of law as generally recognized. Moreover, the compulsory adjudication is an essential condition for peace as the absence of the violence. According to Lauterpacht, peace among nations, as the absence of the violence among nations, can be achieved by different means and the reign of law which incorporates compulsory adjudication is only one of the possibilities (Lauterpacht, 2000, 437). Nevertheless, the peace secured through compulsory adjudication is a different kind of peace and not only the pure absence of force. It enables the realization of the principle of equity and certainty as the general principles of law. In this context we should look at his 
claim that the reign of law, i.e. peace through compulsory adjudication, presents an essential condition of peace, i.e. peace as the pure absence of the force.

The omnis judex principle confirmed in the opinion of the Permanent Court has to be, as a matter of law, inquired into and possibly corrected by the new decisions of the courts. "The international lawyer must not regard himself as being prevented from attempting that task on the ground that the Permanent Court of International Justice has repeatedly expressed the opinion that it is a clear rule of international law that a State cannot be compelled against its will to submit its disputes with other States for international adjudication, and that its jurisdiction is strictly limited by the will of States" (Lauterpacht, 2000, 435).

\section{CONCLUSION: SIMILARITIES AND DIFFERENCES BETWEEN THE KELSEN AND LAUTERPACHT}

In the light of the analysis of Kelsen and Lauterpacht's theories on the connection between the international law and the value of peace we can find two similarities and two differences between them.

Both authors, Kelsen and Lauterpacht have established the connection between peace and law through their conceptions of the law. It can be said that the protection of the value of peace is stipulated by their theories. The protection of the value of peace is the necessary element of their conceptions of law and important for the functioning of the law itself, without a necessary reference to other purposes outside the law. That is why we can consider it as something inherent to the law.

The second similarity between both authors can be seen in their attempts to use the inherent value of peace in the argumentation regarding the norms of the existing system of international law. Kelsen has criticized the existing international legal order grounded on: a) the general prohibition of the use and threat of force by states and b) the possibility of the forcible legal reaction limited only to the cases of the threat or use of force. The argument is based on the conflict between the concept of the value of peace contained in the general international law (i.e. general international law as perceived by Kelsen) and the existing UN rules. Lauterpacht has argued against the omnis judex principle based on the conflict between the existing rule and the general principles of law including the principle on the protection of the value of peace as the inherent value of law.

The first difference is methodological. While Kelsen has tried to unify municipal and international law under the same concept of law by looking for the minimum content identical in both normative systems, Lauterpacht considers that both systems belong to the same concept of law with the maximum content which actually exists in the municipal law.

The second difference between two authors can be seen in the different meanings they ascribe to the value of peace. 
From Kelsen's theory of international law, it is possible to recognize three meanings of the value of international peace. The first one is the Groatian meaning of peace as the minimum of protection of states from the use of force by other states. It is aimed at the control of force by conditioning its use by reasons of law. The second meaning is the value of peace as the absence of any use of force, whatever the reasons could be, but with no reference to the compulsory application of law for all dispute settlements. This meaning of the value of peace is obvious in the existing international law in the norm on prohibition of war together with omnis judex principle. As we have seen, Kelsen takes a very critical attitude to such a state of affairs.

The third meaning is peace through law. As Jochen Rauber has noted, a Kantian peace entails more than the factual absence of the use of force. "In Kantian terms, peace necessarily implies a state of lawfulness, a legal relation between possibly conflicting parties, in short: the rule of law. In sum, his concept of peace not only prohibits the use of force, but encompasses the duty to establish a legal order maintaining the conditions of future peace" (Rauber, 2009, p.60). This Kantian understanding of international peace requires the submission of states to the law and the elimination of situations in which violation of law could arise (Kant, 1917, p. 120). It is similar to the value of the rule of law. This description of the value of peace comes from the combination of the law-operative function related to the process of applying law and the law-regulative function of resolving disputes. It is realized when solutions to international problems are found through applying its general legal standards, that are equal and certain for all states. The international law malfunctions not only when international disputes result in war, but even when international law fails to respond to disputes and such failure presents a potential danger of war. Kelsen describes this sense of law in the following way. "Law is, essentially, an order for the promotion of peace. Its purpose is to assure the peaceful living together of a group of individuals in such a way they may settle their inevitable conflicts in a peaceful manner; that is, without the use of force, in conformity with an order valid for all. This order is the law. Is international law also such an order? And if not, what is the way to make of international law a workable order for the promotion of peace?" (Kelsen, 1948, p. 1). In the same work, Kelsen, as early as 1942, points to the necessity of establishing compulsory adjudication in the international order.

While Lauterpacht remains with the third meaning of the peace as peace through law, Kelsen has changed his position. The similarity between two authors, Kelsen and Lauterpacht, exists in the first period of Kelsen' s work until 1960. After that Kelsen accepted the minimal meaning of the value of peace which is connected with his coercive theory of law while Lauterpacht remains with the conceptual characteristic of the value of peace with the maximum content as the law through peace. This does not mean that Kelsen has necessarily abandoned the role of peace through law as unimportant. The minimum content of the value of peace in the first sense remains within his concept of law while the value of peace through 
law remains for him the matter of de lege ferenda based on the tendencies of the pacification.

\section{References:}

Hart, H.L.A. (2012). The Concept of Law, Third Edition. Oxford: Oxford University Press

Kant, Immanuel (1917). Perpetual Peace, A Philosophical Essay. London: George Allen \& Unwin Ltd.

Kelsen, Hans. (1948). Law and Peace in International Relations, The Oliver Wendell Holmes Lectures, 1940-1941. Cambridge: Harvard University Press.

Kelsen, Hans. (1949). General Theory of Law and State. Cambridge, Massachusetts: Harvard University Press.

Kelsen, Hans. (1951). The Law of the United Nations: A Critical Analysis of Its Fundamental Problems. London: Stevens \& Sons Limited.

Kelsen, Hans. (1952). Principles of International Law. New York: Rinehart and Company.

Hans Kelsen. (2001). Collective Security Under International Law. New Jersey: The Lawbook Exchange

Kelsen, Hans. (2005). Pure Theory of Law, second (revised and enlarged) edition. New Jersey: The Lawbook Exchange, Ltd. Ltd.

Kelsen, Hans. (2008). Peace Through Law. Clark, New Jersey: The Lawbook Exchange,

Kletzer, Christoph. (2018). The idea of a Pure Theory of Law. Oxford and Portland, Oregon: Hart Publishing.

Lissitzyn, Oliver J. (1954). Reviewed Work(s): Principles of International Law by Hans Kelsen. Columbia Law Review, Vol. 54, No.

Lauterpacht, Hersch. (1978). International Law: Volume 1, The General Works: Being the Collected Papers of Hersch Lauterpacht (edited by Elihu Lauterpacht). London: Cambridge University Press.

Lauterpacht, Hersch. (2000). Functions of Law, The Function of Law in the International Community. New Jersey: The Lawbook Exchange, Ltd.

Paulson, Stanley L. (2017a). The Makings of a Radical Norm Theory: Hans Kelsen's Sanction-Norm as Empowering Norm. In: Rechtsphilosophie und Grundrechtstheorie Robert Alexys System. Edited by: Martin Borowski, Stanley L. Paulson, Jan-Reinard Sieckmann, Mohr Siebeck, Tübingen.

Paulson, Stanley L. (2017b). Metamorphosis in Hans Kelsen's Legal Philosophy. The Modern Law Review, Vol. 80, Issue 5. 
Paulson, Stanley L. (2018). Forms and Functions of the Basic Norm, with Special Attention to the 'Systematizing' Function. Presented at the Conference: Hans Kelsen and Contemporary Jurisprudence, Genoa, April 26, 2018.

Rauber Jochen. (2009). The United Nations - a Kantian Dream Come True? Philosophical Perspectives on the Constitutional Legitimacy of the World Organization. Hanse Law Review, vol. 5, no. 1.

Rigaux, Francois. (1998). Hans Kelsen on International Law. European Journal of International Law 9.

\section{SAŽETAK:}

Cilj ovog članka je analizirati ulogu mira u teorijama međunarodnog prava Hansa Kelsena i Hersha Lauterpachta. Posebno će se obraditi promjena u Kelsenovom pristupu ulozi mira nakon 1960 godine. Uz teorijska razmatranja povezanosti mira i prava, oba autora su usmjerili svoje teorije prema praktičnim problemima. Na kraju analize prikazat će se sličnosti i razlike između Kelsena i Lauterpachta.

Ključne riječi: pravna teorija, međunarodno prava, pravne vrijednosti, mir, Kelsen, Lauterpacht 